\title{
PERLINDUNGAN HUKUM TERHADAP \\ PEJABAT PEMBUAT KOMITMEN (PPK) DALAM PENGADAAN BARANG/JASA PEMERINTAH PADA SISTEM PENGADAAN SECARA ELEKTRONIK
}

\begin{abstract}
-Mita Kristiani-
ABSTRAK

Perlindungan hukum atau bantuan hukum kepada pelaku pengadaan barang/jasa pemerintah sejatinya diatur dalam peraturan perundang-undangan terkait, namun perlindungan yang seperti apa belum dijelaskan dan diatur secara rinci dalam peraturan perundang-undangan tersebut. Dikarenakan tidak adanya suatu aturan yang mengatur secara tegas dan jelas terkait dengan perlindungan pelaku pengadaan barang/jasa pemerintah dan kurangnya perhatian dari pemerintah. Sehingga berdasarkan hal tersebut hal yang ditawarkan ialah perlu untuk membuat suatu kebijakan yang mengatur secara jelas dan lengkap terkait dengan perlindungan pelaku pengadaan barang/jasa pemerintah.
\end{abstract}

Kata Kunci: Pengadaan Barang/Jasa Pemerintah, Pejabat Pembuat Komitmen, Perlindungan Hukum

\begin{abstract}
Legal protection or legal assistance for government procurement of goods services is actually regulated in relevant laws and regulations, but what kind of protection has not been explained and regulated in detail in the laws and regulations. Due to the absence of a rule that regulates explicitly and clearly related to the protection of actors in the procurement of government goods/services and the lack of attention from the government. So based on this, the thing offered is the need to make a policy that regulates clearly and completely related to the protection of government procurement of goods/services.
\end{abstract}

Keywords: Procurement of Government Services, Commitment Making Officer, Legal protection

\section{PENDAHULUAN}

Penyelenggaraan pemerintah pada dasarnya merupakan sistem dan proses interaksi sosial politik antara pemerintah dan masyarakat, yang pada umumnya tertuang dalam kontrak sosial yang berwujud konstitusi negara. Dalam kontrak sosial tersebut diatur mengenai hak-hak dan kewajiban, kekuasaan dan kewenangan setiap pihak dalam pelaksanaan penyelenggaraan kehidupan bermasyarakat, berbangsa dan bernegara. Terselenggaranya good governance merupakan prasyarat utama untuk menjalankan tujuan negara khususnya pada penyelenggaraan kesejahteraan masyarakat. ${ }^{1}$ Sejalan dengan besarnya tuntutan masyarakat terhadap pelaksaan good governance, dalam pemenuhan semua aspek kehidupan di masa yang akan datang termasuk di dalamnya kebutuhan terhadap pelayanan publik yang berkualitas. Oleh karena itu, diperlukan perencanaan pembangunan yang sistematis, terarah, menyeluruh, serta tanggap terhadap dinamika

\footnotetext{
${ }^{1}$ Bagir Manan, Peranan Hukum Administrasi Negara dalam Pembentukan Peraturan Perundangan-Undangan" (makalah disampaikan pada Peraturan Nasional Hukum Acara dan Hukum Administrasi Negara Fakultas Hukum Universitas Hasanudin, 26-31 Agustus 1996), hlm. 13
}

tuntutan masyarakat. Dalam upaya pemerintah dengan birokrasinya menyelenggarakan pelayanan publik bagi masyarakat, diperlukan adanya pengembangan dan penerapan sistem pertanggungjawaban yang nyata sehingga penyelenggaraan pemerintah dan pembangunan dapat berlangsung secara berdaya guna, bersih dan akuntabel. ${ }^{2}$

Hal yang tidak dapat dinafikan dalam penyelenggaraan pelayan publik tersebut, perlu adanya pos anggaran pengeluaran yang salah satunya adalah untuk belanja barang dan jasa. Untuk penyelenggaran pemerintah baik dari pemerintah pusat maupun daerah dituangkan dalam anggaran negara dan anggaran daerah termasuk di dalamnya pengadaan barang dan jasa pemerintah. Selain itu, untuk menunjang pembangunan infrastruktur, baik sarana dan prasarana pemerintah diperlukan adanya kegiatan pengadaan, baik berupa barang atau jasa. Dalam pengadaan barang/jasa diperlukan

2 Sedamaryanti, Good Governance dalam Rangka Otonomi Daerah Upaya Membangun Organisasi Efektif dan Efesien Melalui Restrukturisasi dan Pemberdayaan, (Bandung, Mandar Maju, 2003), hlm. 3. 
suatu perencanaan yang baik agar mendapatkan barang yang sesuai dengan kebutuhan.

Dalam penyelenggaraan kehidupan bernegara, pemerintah senantiasa dituntut untuk memajukan kesejahteraan umum. Untuk mengemban kewajiban ini, pemerintah mempunyai kewajiban menyediakan kebutuhan rakyat dalam berbagai bentuk baik berupa barang, jasa maupun pembangunan infrastruktur. Di sisi lain, pemerintah juga memerlukan barang dan jasa itu dalam melaksanakan kegiatan pemerintahan. ${ }^{3}$ Pengadaan barang/jasa (procurement) pada hakekatnya merupakan salah satu upaya untuk mewujudkan barang dan jasa yang di inginkan dengan metode dan proses tertentu untuk mencapai kesepakatan harga, waktu, dan kesepakatan lainnya. Kegiatan pengadaan barang/jasa ini dituangkan dalam suatu perjanjian atau kontrak pengadaan barang/jasa. ${ }^{4}$

Sejalan dengan kebijakan demokratisasi dan desentralisasi, proses pengadaan (procurement) barang dan jasa di Indonesia kini tidak lagi dilaksanakan secara sentralistis. Diantara jajaran pemerintah pusat, mekanisme pengadaan tidak lagi dilaksanakan oleh sebuah departemen teknis saja tetapi dilaksanakan di dalam sebuah sistem yang melibatkan banyak kementerian dan lembaga yang masing-masing berbeda fungsi dan peranannya. ${ }^{5}$ Desentralisasi juga mengharuskan bahwa pengadaan tidak hanya melibatkan perumus kebijakan di jajaran pemerintah pusat tetapi juga pemerintah daerah, baik di tingkat provinsi maupun di tingkat kabupaten/kota. Diharapkan bahwa dengan sistem yang lebih demokratis, desentralistis dan terbuka ini proses pengadaan akan lebih efektif, efisien dan akuntabel. ${ }^{6}$

Pengadaan Barang/Jasa Pemerintah yang selanjutnya disebut Pengadaan Barang/Jasa adalah kegiatan Pengadaan Barang/Jasa oleh Kementerian/Lembaga/Perangkat Daerah yang dibiayai oleh APBN/APBD yang prosesnya sejak identifikasi kebutuhan, sampai dengan serah terima hasil pekerjaan. ${ }^{7}$ Pemerintah saat

\footnotetext{
Yohanes Sogar Simamora, Hukum Perjanjian_Prinsip Hukum Kontrak Pengadaan Barang dan Jasa oleh Pemerintah, (Yogyakarta: LaksBang PRESSindo, 2009), hlm.1.

${ }^{4}$ ICW, Prinsip Dasar Kebijakan Dan Kerangka Hukum Pengadaan Barang dan Jasa, Jakarta, Indonesian Procurement Watch, 2005, hlm. 5

5 No Name, Laporan Tahunan, Artikel dalam (http://bagianpbj.kutaibaratkab.go.id/wpcontent/uploads/2017/09/Laporan-Tahunan-2017-BagianPBJ-website.pdf), diakses pada tanggal 10 Mei 2008
}

ini telah melakukan regulasi dalam proses pengadaan barang dan jasa yang diharapkan efesien, terbuka dan kompetitif, terjangkau dan berkualitas. Untuk meningkatkan efisien dan efektifitas penggunaan keuangan negara yang dibelanjakan melalui proses pengadaan/jasa pemerintah, diperlukan upaya untuk menciptakan keterbukaan, transparansi, akuntabel serta prinsip persaingan/kompetisi yang sehat dalam proses pengadaan barang/jasa pemerintah yang dibiayai oleh Anggaran Pendapatan dan Belanja Negara yang selanjutnya dalam hal ini disebut (APBN)/Anggaran Pendapatan dan Belanja Daerah yang selanjutnya dalam hal ini disebut APBD, sehingga diperoleh barang/jasa yang terjangkau dan berkualitas serta dapat dipertanggung jawabkan baik dari segi fisik, keuangan maupun manfaatnya bagi kelancaran tugas pemerintah dalam pelayanan masyarakat. ${ }^{8}$

Peraturan yang mengatur tentang pengadaan barang/jasa pemerintah sendiri, adalah Peraturan Presiden Nomor 54 tahun 2010 Tentang Pengadaan Barang/Jasa Pemerintah, hingga saat ini telah mengalami lima kali perubahan, yaitu perubahan pertama melalui Pepres Nomor 35 tahun 2011; perubahan kedua melalui Perpres Nomor 70 tahun 2012; perubahan ketiga melalui Perpres Nomor 172 tahun 2014 kemudian Perpres Nomor 4 tahun 2015, dan yang terakhir adalah Perpres Nomor 16 Tahun 2018 diundangkan pada Maret 2018, dan berlaku mulai 1 Juli 2018. Setiap perubahan dalam peraturan mengenai pengadaan barang/jasa pemerintah ini dilakukan untuk menyempurnakan/melengkapi aturan sebelumnya, serta disesuaikan dengan kondisi di lapangan terkait proses pengadaan barang/jasa pemerintah.

Dengan diundangkannya peraturan tersebut maka peraturan yang berlaku sebelumnya, yakni Perpres Nomor 54 Tahun 2010 sampai dengan Perpres Nomor 4 tahun 2015 tentang Pengadaan Barang/Jasa Pemerintah, dicabut dan dinyatakan

6 Wahyudi Kumorotomo, Jurnal Masalah Kelembagaan Dalam Reformasi Pengadaan Barang Dan Jasa Di Indonesia

7 Pasal 1 angka 1 Peraturan Presiden Republik Indonesia Nomor 16 tahun 2018 tentang Pengadaan Barang/Jasa Pemerintah.

8 Penjelasan Atas Peraturan Presiden Republik Indonesia Nomor 54 tahun 2010 Tentang Pengadaan Barang/Jasa Pemerintah 
tidak berlaku. ${ }^{9}$ Salah satu pertimbangan diundangkan Perpres ini adalah bahwa Peraturan Presiden terdahulu masih terdapat kekurangan dan belum menampung perkembangan kebutuhan pemerintah mengenai pengaturan atas Pengadaan Barang/Jasa yang baik.

Dalam penyelenggaraan pengadaan barang dan jasa tentu tidak terlepas dari para pihak yang mendukung dan terlibat dalam pelaksanaan kegiatan tersebut. Para pihak yang terkait dalam penyelenggara pengadaan barang/jasa terdiri dari Pengguna Anggaran (PA), Kuasa Pengguna Anggaran (KPA), Pejabat Pembuat Komitmen (PPK), Pejabat Pengadaan, Kelompok Kerja Pemilihan (Pokja Pemilihan), Agen Pengadaan, Pejabat Pemeriksa Hasil Pekerjaan (PjPHP)/ Panitia Pemeriksa Hasil Pekerjaan (PPHP), Penyelenggara Swakelola dan Penyedia Barang/Jasa. ${ }^{10}$ Salah satu pelaksana pengadaan barang/jasa adalah Pejabat Pembuat Komitmen yang selanjutnya dalam hal ini akan disebut (PPK) adalah pejabat yang bertanggung jawab atas pelaksanaan Pengadaan Barang/Jasa. di lingkungan birokrasi maka akan sangat akrab dengan istilah PPK. Istilah lamanya pimpinan proyek atau pimpinan bagian proyek. PPK merupakan tokoh penting dalam pengadaan barang dan jasa, karena PPK merupakan orang yang bertanggung jawab atas pelaksanaan pengadaan barang/jasa. Sehingga PPK bertanggung jawab secara administrasi, teknis dan financial terhadap pengadaan barang dan jasa. ${ }^{11}$ Berdasarkan ketentuan Pasal 1 angka 10 Perpres Nomor 16 tahun 2018 tentang Pengadaan Barang/Jasa Pemerintah, mendefinisikan PPK adalah pejabat yang diberi kewenangan oleh Pengguna Anggaran/ Kuasa Pengguna Anggaran untuk mengambil keputusan dan/ atau melakukan tindakan yang dapat mengakibatkan pengeluaran anggaran belanja negara/anggaran belanja daerah. ${ }^{12}$

PPK tidak bekerja pada akhir pengadaan, tetapi PPK sudah mulai bekerja sejak perencanaan pengadaan samapai akhir pelaksanaan pengadaan. Hal ini karena PPK adalah orang yang paling mengetahui tentang barang/jasa yang akan diadakan. Oleh sebab itu,

9 Pasal 92 Peraturan Presiden Republik Indonesia Nomor 16 tahun 2018 tentang Pengadaan Barang/Jasa Pemerintah

${ }_{10}$ Pasal 8 Peraturan Presiden Republik Indonesia Nomor 16 tahun 2018 tentang Pengadaan Barang/Jasa Pemerintah apabila terjadi kesalahan pada proses pengadaan barang/jasa yang disebabkan karena kesalahan perencanaan, maka PPK juga bertanggung jawab terhadap hal tersebut. Di era lama, orang menganggap jabatan PPK merupakan"jabatan basah", karena "memakmurkan" orang yang menjabatnya. Sehingga banyak pejabat struktural berlomba-lomba untuk menjadi PPK. Tetapi di era reformasi ini, jabatan PPK menjadi momok bagi birokrat. Alasannya tidak lain karena PPK sangat rentan dengan masalah hukum, terkait dengan pelaksanaan kontrak ataupun permasalahan lain terkait masalah pengadaan barang/jasa pemerintah. Akan sangat lazim dijumpai kasus tindak pidana korupsi terkait Pengadaan Barang/Jasa, pastilah menyeret PPK dan penyedia barang/jasa. Hal ini merupakan konsekuensi yuridis dari dokumen kontrak yang dibuat oleh PPK dan Penyedia Barang/Jasa.

Sektor pengadaan barang dan jasa merupakan wilayah yang rentan dikorupsi sepanjang 2017. Indonesia Corruption Watch (ICW) mencatat tahun 2017 sudah ada 84 kasus yang diproses hukum dengan kerugian negara mencapai Rp 1,02 Triliun. Sektor pelayanan publik sangat rentan untuk dikorupsi dalam proses Pengadaan Barang dan Jasa (PBJ). Sepanjang tahun 2017 sedikitnya ada sekitar 84 kasus korupsi yang diproses oleh aparat penegak hukum (APH) pada sektor pelayanan publik dengan total nilai kerugian negara sebesar $\mathrm{Rp}$ 1,02 triliun, kata Staf Divisi Investigasi ICW Wana Alamsyah di kantor ICW, Jl Kalibata Timur, Jakarta Selatan. ${ }^{13}$

Menjadi sebuah realita bahwa para penyelenggara pengadaan barang/jasa merasa tidak nyaman dan terusik serta was-was dalam menyelenggarakan pengadaan barang/jasa akibat kerapkali aparat penegak hukum (baik oknum polisi dan/atau oknum kejaksaan) melakukan pemanggilan dan/atau pemeriksaan terhadap penyelenggara yang tengah menyelenggarakan pengadaan barang/jasa. Sering kali didasarkan dengan alasan bahwa adanya laporan dari pihak-pihak (masyarakat, Lembaga Swadaya Masyarakat ataupun pihak

11 http://p3i.or.id/pejabat-pembuat-komitmen-tidakwajib-eselon-eselon-tidak-harus-menjadi-pejabatpembuat-komitmen/, diakses pada 10 Mei 2018.

12 Pasal 1 angka 10 Peraturan Presiden Republik Indonesia Nomor 16 tahun 2018 tentang Pengadaan Barang/Jasa Pemerintah

13 https://news.detik.com/berita/3885311/icwkorupsi-pengadaan-barang-2017 
yang terkait dalam penyelenggara pengadaan barang/jasa yang mengindikasikan adanya penyimpangan prosedur dan pelanggaran hukum dalam penyelenggaraan pengadaan barang/jasa. ${ }^{14}$

Maraknya pemberitaan dan banyaknya masalah yang dihadapi oleh PPK dalam pelaksanakan tugas dan kewenangannya yang berujung pada jeruji besi pada akhirnya membuat ciut nyali seorang Pegawai Negeri Sipil atau Aparatur Sipil Negara dalam melaksanakan tugasnya selaku PPK atau pun ketika di tunjuk sebagai PPK. Perlindungan hukum yang masih belum jelas dan dipertanyakan terhadap kasus-kasus seperti ini pada akhirnya membuat PPK tidak ingin mengambil resiko bagi karirnya.

Sebagaimana diuraikan sebelumnya bahwa terdapat kekhawatiran bagi PPK dalam menyelenggarakan proses Pengadaan barang/jasa terhadap adanya pemeriksaan dari kepolisian dan kejaksaan. Seperti diketahui bahwa PPK dalam hal ini mempunyai kewenangan sebagaimana yang telah ditetapkan dalam Peraturan yang secara khusus mengatur terkait dengan pelaksanaan pengadaan barang dan jasa, namun dalam hal ini PPK masih merasa dikebiri seolah-olah apa yang diperbuat merupakan sebuah kesalahan dan akan diproses hukum walaupun proses pengadaan barang dan jasa sudah diupayakan sesuai dengan prosedur atau mekanisme yang diatur dalam peraturan perundang-undangan. Untuk itu perlu diketahui perlindungan hukum yang diberikan oleh undang-undang ataupun peraturan lainnya terkait dengan jabatan PPK, untuk menjamin hak-hak dari PPK sebagai pejabat yang ditunjuk dan terpilih dan diberikan kewenangan oleh pemerintah dalam menyelenggarakan kegiatan pengadaan barang dan/jasa. Karena sampai saat ini, tidak ada jaminan bagi penyelenggara untuk tidak diperiksa oleh kepolisian dan kejaksaan walaupun tidak ada ditemukannya indikasi tindak pidana. Setiap saat pihak kepolisian dan kejaksaan bisa saja melakukan pemanggilan dan pemeriksaan bagi penyelenggara pengadaan barang dan jasa termasuk PPK.

Aktivitas belanja publik pada pemerintah daerah ini menjadi perhatian penting, karena mempertimbangkan pengeluaran atau penggunaan dana publik. Perlu adanya

14 Anonimous, Modul 10, Penggunaan Eprocurement Pelatihan Tingkat Dasar Pengadaan Barang/Jasa Pemerintah Berdasarkan Peraturan Presiden pengawasan dan pengendalian internal dalam pengadaan barang maupun belanja modal, karena dari adanya kegiatan pengadaan barang ini dimungkinkan terjadi tindak korupsi, kolusi, dan nepotisme (KKN). Kekhawatiran akan terjadinya kecurangan-kecurangan pada aktivitas belanja publik tersebut semakin mendorong pemerintah menerapkan suatu sistem pengadaan barang dan jasa, salah satu caranya yaitu dengan pengadaan secara elektronik (e-procurement). Pengadaan barang dan jasa secara elektronik yang diterapkan merupakan sistem pengadaan barang dan jasa yang proses pelaksanaannya dilakukan secara elektronik dengan memanfaatkan fasilitas komunikasi dan informasi melalui internet dan sistem aplikasi serta layanan pengadaan eletronik yang disediakan oleh Layanan Pengadaan Secara Elektronik (LPSE) dari Lembaga Kebijakan Pengadaan Barang/Jasa Pemerintah (LKPP).

Pelaksanaan pengadaan secara elektronik di harapkan bisa transparan dan akuntabel sesuai dengan prinsip-prinsip pengadaan barng/jasa pemerintah. Pengawasan yang ketat dan transparansi melalui pengadaan secara elektronik tidak memungkiri masih ada kekurangan ataupun celah kesalahan yang berakibat pada permasalahan hukum, Pejabat Pembuat Komitmen sebagai ujung tanduk pelaksanaan pengadaan berperan penting dalam pelaksanaan pengadaan.

\section{PEMBAHASAN}

\section{Perlindungan Hukum terhadap Pejabat Pembuat Komitmen dalam Pengadaan Barang/Jasa Pemerintah Pada Sistem Pengadaan Secara Elektronik}

Pengadaan barang/jasa pemerintah secara elektronik meliputi $e$-tendering dan atau $e$ purchasing. E-tendering adalah tata cara pemilihan Penyedia Barang/Jasa yang dilakukan secara terbuka dan dapat diikuti oleh semua Penyedia Barang/Jasa yang terdaftar pada sistem pengadaan secara elektronik dengan cara menyampaikan 1 (satu) kali penawaran dalam waktu yang telah dengan menggunakan sistem pengadaan elektronik yang diselenggarakan oleh LPSE. Sedangkan E-Purchasing adalah tata cara pembelian Barang/Jasa melalui sistem katalog elektronik. Dimana yang dimaksud dengan

No. 54 Tahun 2010 Beserta Perubahannya, Deputi Bidang PPSDM, LKPP, 2014, hlm. 4 
katalog elektronik atau E-Catalogue adalah sistem informasi elektronik yang memuat daftar, jenis, spesifikasi teknis dan harga barang tertentu dari berbagai Penyedia Barang/Jasa Pemerintah.

Adapun maksud dan tujuan dari pengadaan barang/jasa pemerintah secara elektronik ini ialah untuk meningkatkan transparansi dan akuntabilitas, meningkatkan akses pasar dan persaingan usaha yang sehat, mendukung proses monitoring dan audit, dan memenuhi kebutuhan akses informasi yang real time.

\section{a. Perlindungan Hukum Berdasarkan Undang-Undang Nomor 5 Tahun 2014 tentang Aparatur Sipil Negara (ASN)}

Karena pelaku pengadaan barang/jasa pemerintah yang dalam hal ini adalah Pejabat Pembuat Komitmen (PPK) juga termasuk ke dalam Aparatur Sipil Negara (ASN), maka seharusnya PPK dalam melaksanakan tugas dan fungsinya mendapatkan perlindungan hukum. Dalam Undang-Undang Nomor 5 Tahun 2014 tentang Aparatur Sipil Negara (ASN) tidak mengatur secara jelas terkait dengan perlindungan hukum terhadap ASN.

Korps profesi ASN Republik Indonesia memiliki fungsi perlindungan sebagaimana tercantum dalam Pasal 126 Ayat (3) huruf b yang menyatakan "memberikan perlindungan hukum dan advokasi kepada anggota korps profesi ASN Republik Indonesia terhadap dugaan pelanggaran Sistem Merit dan mengalami masalah hukum dalam melaksanakan tugasnya".

Dalam Undang-undang ini hanya menjelaskan bahwa ASN berhak mendapatkan perlindungan hukum dan advokasi. Namun, perlindungan hukum yang bagaimana tidak dijelaskan secara mendetail dalam Undangundang ini, bahkan tidak ada Pasal satupun yang menjelaskan secara eksplisit bentuk perlindungan hukum yang seharusnya didapatkan. Hal inilah yang mengakibatkan ketika ASN dalam hal ini PPK selaku bagian dari pelaku pengadaan barang/jasa pemerintah melakukan pelanggaran atau tindakan yang mengakibatkan suatu perbuatan pidana belum mendapatkan perlindungan hukum dari pemerintah.

Hal ini berdasarkan fakta yang terjadi selama ini, bahwa pelaku pengadaan barang/jasa pemerintah yang diduga atau terkena kasus pidana dalam penyelenggaraan barang/jasa pemerintah dalam menghadapi kasus tersebut berjalan sendiri dengan membayar pengacara atau penasehat hukum sendiri. Selama ini belum ada perlindungan yang diberikan oleh pemerintah terkait dengan kasus pelanggaran dalam penyelenggaraan barang/jasa pemerintah yang dilakukan oleh PPK maupun pelaku pengadaan barang/jasa secara keseluruhan.

b. Perlindungan Hukum Berdasarkan Peraturan Pemerintah Nomor 11 Tahun 2017 tentang Manajemen Pegawai Negeri Sipil

Perlindungan hukum dalam Peraturan Pemerintah Nomor 11 Tahun 2017 tentang Manajemen Pegawai Negeri Sipil diatur dalam Pasal 308 huruf d yaitu pemerintah wajib memberikan perlindungan berupa bantuan hukum. Bantuan hukum sebagaimana dimaksud di atas, berupa pemberian bantuan hukum dalam perkara yang dihadapi di pengadilan terkait pelaksanaan tugasnya.

Pelaku pengadaan barang/jasa pemerintah dalam hal ini ialah Pejabat Pembuat Komitmen (PPK) merupakan Pegawai Negeri Sipil (PNS) yang dalam hal ini termasuk juga dalam Peraturan Pemerintah tersebut. Dimana, pelaku pengadaan barang/jasa pemerintah juga berhak mendapatkan perlindungan hukum berupa bantuan hukum sebagaimana diatur dalam Peraturan Pemerintah tersebut.

Namun demikian Peraturan Pemerintah No 11 Tahun 2017 tersebut belum mengatur secara jelas hal-hal yang dimaksud dengan perlindungan hukum tersebut. Karena kurang tegasnya pengaturan perlindungan hukum tersebut dalam Peraturan Pemerintah dimaksud, sehingga saat ini masih dirasakan oleh Pegawai Negeri Sipil (pelaku pengadaan barang/jasa pemerintah) yang terkena masalah hukum, ketiadaan perlindungan hukum.

c. Perlindungan Hukum terhadap Pelaku Pengadaan Barang/Jasa Pemerintah Berdasarkan Peraturan Presiden Nomor 16 Tahun 2018 tentang Pengadaan Barang/Jasa Pemerintah

Di dalam Peraturan Presiden Nomor 16 Tahun 2018 tentang Pengadaan Barang/Jasa Pemerintah tidak mengatur secara khusus terkait dengan perlindungan hukum terhadap pelaku pengadaan barang/jasa dalam hal ini ialah Pejabat Pembuat Komitmen (PPK).

Perlindungan dalam ilmu hukum adalah suatu bentuk pelayanan yang wajib diberikan oleh aparat penegak hukum atau aparat keamanan untuk memberikan rasa aman, baik fisik maupun mental, kepada korban dan sanksi dari ancaman, gangguan, teror, dan kekerasan dari pihak manapun yang diberikan pada tahap 
penyelidikan, penyidikan, penuntutan, dan atas pemeriksaan di sidang pengadilan. Perlindungan hukum adalah suatu perlindungan yang diberikan terhadap subyek hukum dalam bentuk perangkat hukum baik yang bersifat preventif maupun yang bersifat represif, baik yang tertulis maupun tidak tertulis. Dengan kata lain perlindungan hukum sebagai suatu gambaran dari fungsi hukum yaitu konsep dimana hukum dapat memberikan suatu keadilan, ketertiban, kepastian, kemanfaatan dan kedamaian.

Adanya perlindungan hukum bagi seseorang berarti bahwa ia mendapat jaminan akan adanya perlindungan secara hukum terhadap suatu perbuatan hukum yang dilakukannya. Begitu juga halnya bagi pelaku pengadaan dalam tugasnya melaksanakan pengadaan barang/jasa pemerintah, agar terciptanya rasa keadilan, ketertiban, kepastian, kemanfaatan dan kedamaian. Keadilan berarti bahwa apa yang dilakukan pelaku pengadaan yang sudah sesuai dengan ketentuan seyogyanya memperoleh imbalan yang sesuai dengan hasil kerja yang dilakukannya.

Salah satu upaya perlindungan hukum yang dijamin pemerintah bagi pelaku pengadaan sebagaimana tertuang di dalam Pasal 84 ayat (1) Peraturan Presiden Nomor 16 Tahun 2018 tentang Pengadaan Barang/Jasa Pemerintah, yang menyatakan bahwa Pimpinan Kementerian, Lembaga, Pemerindah Daerah wajib memmberikan pelayanan hukum kepada Pelaku Pengadaan Barang/Jasa dalam menghadapi permasalahan hukum terkait pengadaan barang/jasa.

Pelayanan hukum sebagaimana dimaksud diatas diberikan sejak proses penyelidikan hingga tahap putusan pengadilan. Pelaku Pengadaan sebagaimana di atas dikecualikan untuk Penyedia, Ormas, kelompok masyarakat penyelenggara swakelola, dan Pelaku Usaha yang bertindak sebagai Agen Pengadaan.

Optimalisasi pengendalian dan pengawasan pelaksanaan pengadaan dari PA/KPA sebagai pengguna, dimulai dari perencanaan sampai dengan selesai, merupakan upaya perlindungan preventif menghindari permasalahan hukum di kemudian hari.

Diskresi adalah Keputusan dan/atau Tindakan yang ditetapkan dan/atau dilakukan oleh Pejabat Pemerintahan untuk mengatasi

15 Grasia Kurniati, Akibat Hukum Pelanggaran Prosedur Pengadaan Barang/Jasa Pemerintah dan Perlindungan Hukum Terhadap Organisasi Pengadaan persoalan konkret yang dihadapi dalam penyelenggaraan pemerintahan dalam hal peraturan perundang-undangan yang memberikan pilihan, tidakmengatur, tidak lengkap atau tidak jelas, dan/atau adanya stagnasi pemerintahan. ${ }^{15}$

Pelaksanaan pengadaan atau pelaksanaan kontrak pemerintah, telah tersedia peraturan perundang-undangannya yang terkait, misalnya dengan peraturan pekerjaan konstruksi atau peraturan keuangan, dengan demikian pelaksanaan pengadaan harus patuh pada peraturan. Jika peraturan pengadaan atau pelaksanaan kontrak sulit atau tidak dapat dijalankan, maka dapat diambil keputusan diskresi. Namun, jika telah diambil keputusan diskresi jangan sampai terjadi perbuatan yang mengarah kepada tindak pidana korupsi dan kerugian negara serta harus berkonsultasi dengan APIP/ BPKP/ LKPP. ${ }^{16}$

Selanjutnya, yang harus mendapat atensi dari semua pihak yang terkait pelaksanaan pengadaan barang/jasa pemerintah adalah disampaikan 8 perintah Presiden Jokowi dalam rapat dengan Kajati dan Kapolda se- Indonesia pada tanggal 19 Juli 2016 , yaitu sebagai berikut:

1) Kebijakan dan diskresi pemerintah daerah tidak boleh di pidanakan;

2) Tindakan administrasi harus dibedakan dengan yang memang berniat korupsi. Aturan BPK jelas, mana yang pengembalian dan bukan;

3) Temuan BPK masih diberi peluang perbaikan 60 hari. Sebelum waktu itu habis, penegak hukum tidak boleh masuk dulu;

4) Kerugian negara harus konkret, tidak mengada-ada;

5) Kasus dugaan korupsi tidak boleh diekspose di media secara berlebihan sebelum tahap penuntutan;

6) Pemda tidak boleh ragu mengambil terobosan untuk membangun daerah;

7) Perintah ada pengecualian untuk kasus dugaan korupsi yang berawal dari operasi tangkap tangan (OTT); dan

8) Setelah perintah itu, jika masih ada kriminalisasi kebijakan, KapoldaKapolres dan Kajati-Kajari akan dicopot.

Barang/Jasa Pemerintah, Jurnal Hukum POSITUM Vol. 1 No. 2, Juni 2017, hlm. 321-325

${ }^{16} \mathrm{Ibid}, \mathrm{hlm} .325$ 
Dengan demikian, memperhatikan pendapat Mudji Santosa dan 8 perintah Presiden Jokowi terlihat atensi pemerintah sangat besar dan pentingnya perlindungan hukum bagi pelaku pengadaan dalam tugas dan fungsinya melaksanakan pengadaan barang/ jasa pemerintah. Selanjutnya, 8 perintah Presiden Jokowi mempertegas dikeluarkannya Peraturaturan Presiden dan Instruksi Presiden.

Disamping itu, sejak diterbitkannya Peraturan Presiden (Prespres) pertama kali sampai dengan sekarang Perpres terbaru, tidak sama sekali mengatur secara jelas mengenai perlindungan hukum kepada pelaku pengadaan barang/jasa pemerintah khususnya Pejabat Pembuat Komitmen (PPK). Sejak awal diterbitkannya Perpres ini hanya mengatur tata cara pelaksanaan pengadaan barang/jasa pemerintah beserta kewenangan dan tugas PPK saja.

d. Perlindungan Hukum Berdasarkan

Pengaturan Dewan Pengurus Korps Pegawai Republik Indonesia Nomor 01 Tahun 2017

Korps Pegawai Republik Indonesia yang selanjutnya disingkat KORPRI merupakan wadah bagi anggota perhimpunan seluruh pegawai Republik Indonesia, yang meliputi PNS dan pegawai LPNK/BUMN/BUMD/BHP/LPP/BLU/ Badan Otorita/ Kawasan Ekonomi Khusus demi meningkatkan perjuangan, pengabdian, serta kesetiaan kepada cita-cita perjuangan Bangsa dan Negara Kesatuan Republik Indonesia berdasarkan keputusan Menteri Hukum dan Hak Asasi Manusia Nomor AHU-00272.60.10 Tahun 2014 tanggal 30 Juni 2014.

Berdasarkan pengaturan Dewan Pengurus KORPRI tersebut, setiap anggota Korpri berhak mendapatkan bantuan dan perlindungan hukum melalui BKBH Korpri dengan cuma-cuma (Prodeo). Pasal 4 Pengaturan Dewan Pengurus KORPRI menyatakan bahwa "LKBH KORPRI bersifat Cuma-cuma (Prodeo) dalam pendampingan hukum bagi anggota KORPRI dan keluarganya yang menghadapi masalah hukum baik di dalam proses peradilan maupun di luar peoses peradilan.

Namun pada faktanya, pelaku pengadaan barang/jasa pemerintah yang dalam hal ini merupakan bagian dari perhimpunan Korpri

${ }^{17}$ Mirhan Triandi, Mendorong (Kembali) Lahirnya Undang-Undang Pengadaan Barang/Jasa, Artikel dalam (https://birokratmenulis.org/mendorong-kembali-lahirnya- dalam menyelesaikan permasalahan hukum yang ditimbulkan akibat pekerjaan atau profesinya cenderung menghadapi masalah hukumnya sendiri dengan memakai jasa Pengacara, tidak ada sama sekali bantuan hukum yang diberikan oleh BKBH KORPRI yang sebagaimana diatas telah dijelaskan.

\section{Bentuk Perlindungan Hukum yang Ideal untuk Pejabat Pembuat Komitmen dalam Pengadaan Barang/Jasa Pemerintah Pada Sistem Pengadaan Secara Elektronik}

Sebelum membahas dan menganalisis bentuk perlindungan hukum yang ideal bagi pelaku pengadaan barang/jasa pemerintah khususnya Pejabat Pembuat Komitmen (PPK), maka terlebih dahulu perlu untuk diketahui dan dikaji terkait dengan penyebab kenapa sampai hari ini pelaku pengadaan barang/jasa pemerintah khususnya Pejabat Pembuat Komitmen (PPK) belum terlindungi baik yang melakukan pengadaan secara manual ataupun secara elektronik.

a. Tidak Adanya Regulasi yang Secara Khusus Mengatur Terkait Perlindungan Hukum Kepada Pelaku PBPJ Khususnya Pejabat Pembuat Komitmen (PPK)

Baru-baru ini lahir Peraturan Presiden Nomor 16 Tahun 2018 tentang Pengadaan Barang/Jasa Pemerintah yang disambut gembira oleh para pelaku pengadaan barang/jasa pemerintah. Namun pada kenyataannya, hingga saat ini tidak ada jaminan bagi pelaku pengadaan barang/jasa pemerintah untuk tidak diperiksa oleh Aparat Penegak Hukum walau indikasi tindak pidananya belum ditemukan.

Aparat Penegak Hukum biasanya cenderung mengabaikan peraturan presiden tentang pengadaan barang/jasa pemerintah ketika sedang melakukan pemeriksaan terhadap pelaku pengadaan barang/jasa. Mereka seringkali hanya terpaku pada undang-undang tindak pidana korupsi dan Kitab UndangUndang Hukum Acara Pidana (KUHAP). ${ }^{17}$

Hal tersebut membuat aspek-aspek spesifik dari proses pengadaan barang/jasa tidak tercermin di dalam pemeriksaan. Tentu saja kecenderungan itu akan mengakibatkan besarnya kemungkinan kriminalisasi bagi

undang-undang-pengadaan-barang-jasa/), diakses tanggal 09 Februari 2019 
pelaku pengadaan barang/jasa pemerintah. Ditambah, perlindungan hukum terhadap pelaku pengadaan barang/jasa pemerintah bisa dikatakan sangat lemah.

Di dalam Peraturan Presiden Nomor 16 Tahun 2018 tentang Pengadaan Barang/Jasa Pemerintah (PBJP) tidak mengatur secara tegas terkait dengan perlindungan hukum terhadap Pejabat Pembuat Komitmen (PPK) dalam Pengadaan Barang/Jasa Pemerintah (PBJP), bahkan dalam Peraturan Presiden tersebut tidak ada bab khusus yang mengatur terkait perlindungan hukumnya. Sehingga hal tersebut menimbulkan ketakutan bagi pelaku pengadaan barang/jasa dalam menjalankan tugas dan fungsinya masing-masing sebagai pelaku pengadaan barang/jasa pemerintah.

Selanjutnta di dalam Peraturan Pemerintah Nomor 11 Tahun 2017 tentang Manajemen Pegawai Negeri Sipil juga mengatur terkait dengan perlindungan hukum, akan tetapi sama halnya dengan Peraturan Presiden diatas, Peraturan Pemerintah tersebut tidak mengatur secara jelas dan tegas hal-hal yang dimaksud dengan perlindungan hukum. Karena kurang tegasnya pengaturan perlindungan hukum tersebut dalam Peraturan Pemerintah ini, sehingga hal tersebut masih dirasakan oleh Pegawai Negeri Sipil khusunya Pelaku pengadaan barang/jasa pemerintah (PBJP) yang terkena masalah hukum.

Untuk memberikan gambaran mengenai ketidaktegasan Peraturan Pemerintah Nomor 11 Tahun 2017 Tentang Manajeman Pegawai Negeri Sipil, dari perspektif hukum dapat ditemui dalam Pasal 92 Ayat (2). Yang berbunyi: "Berita acara ditandatangani oleh pejabat yang mengambil sumpah/janji Jabatan, PNS yang mengangkat sumpah/janji Jabatan, dan saksi”. Dalam arti demikian Pasal 92 ayat (2) ini membuka peluang optional yang berbunyi: "PNS dapat diberhentikan dengan hormat atau tidak diberhentikan karena dihukum penjara berdasarkan putusan pengadilan yang telah memiliki kekuatan hukum tetap karena melakukan tindak pidana dengan hukuman pidana penjara paling singkat 2 (dua) tahun dan pidana yang dilakukan tidak berencana".

Tidak hanya dalam Peraturan Presiden dan Peraturan Pemerintah saja yang tidak mengatur secara jelas terkait dengan perlindungan hukumnya, akan tetapi di dalam peraturan perundang-undangan lainnya juga tidak mengatur terkait dengan perlindungan hukum terhadap pelaku pengadaan barang/jasa pemerintah. Seperti halnya undang-undang tentang Aparatur Sipil Negara (ASN) Nomor 5 Tahun 2014 yang juga tidak mengatur secara jelas terkait perlindungan terhadap ASN. Dalam Pasal 126 Ayat (3) huruf b menyatakan "memberikan perlindungan hukum dan advokasi kepada anggota korps profesi ASN Republik Indonesia terhadap dugaan pelanggaran Sistem Merit dan mengalami masalah hukum dalam melaksanakan tugasnya". Namun perlindungan hukum yang seperti apa dan bagaimana disini belum jelas.

\section{b. Tidak Adanya Perhatian Khusus dari Pemerintah Daerah Kepada Pelaku PBJP Khususnya Pejabat Pembuat Komitmen (PPK)}

Pengadaan barang/jasa merupakan suatu hal penting dalam pembangunan Negara, oleh sebab itu pengadaan barang/jasa perlu mendapatkan perhatian khusus dari pemerintah baik pusat maupun daerah dalam pelaksanaannya. Seharusnya di era otonomi daerah seperti sekarang ini, Pemerintah daerah lebih aktif dalam memberikan perlindungan hukum dan bantuan hukum kepada ASN khususnya para Pelaku Pengadaan Barang/Jasa Pemerintah (PPK). Sampai saat ini, seringkali terjadi permasalahan dalam proses pengadaan barang/jasa pemerintah. Permasalahan tersebut cenderung ke masalah pidana yaitu tindak pidana korupsi yang dilakukan oleh pelaku pengadaan barang/jasa pemerintah.

Sejauh ini, belum ada perhatian khusus dari pemerintah khususnya bagi pemerintah daerah kepada pelaku pengadaan barang/jasa pemerintah yang dalam hal ini adalah Pejabat Pembuat Komitmen (PPK) yang terkena masalah hukum, padahal di era otonomi daerah seperti sekarang Pemerintah Daerah seharusnya lebih aktif dalam memberikan perlindungan hukum dan bantuan hukum. Selama ini para pelaku pengadaan barang jasa yang terlibat kasus hukum berjalan sendiri tanpa adanya bantuan ataupun perhatian dari pemerintah, dengan menggunakan bantuan hukum dari Pengacara yang ia bayar dengan uang sendiri. Padahal di dalam Undang-undang, baik Undangundang Nomor 5 Tahun 2014 tentang Aparatur Sipil Negara, Peraturan Pemerintah Nomor 11 Tahun 2017 tentang Manajemen PNS, maupun berdasarkan Peraturan Presiden Nomor 16 Tahun 2018 tentang Pengadaan Barang/Jasa Pemerintah, pelaku pengadaan barang/jasa yang selaku Pegawai Negeri Sipili (PNS) berhak mendapatkan perlindungan hukum. Namun 
sampai sejauh ini hal tersebut tidak pernah didapatkan oleh mereka yang terkena permasalahan hukum dalam proses pengadaan barang/jasa tersebut.

Seperti contoh kasus yang terjadi pada Pejabat Pembuat Komitmen Kantor Wilayah (Bea Cukai) Jawa Timur Agus Kuncoro yang telah divonis hukuman penjara satu tahun dan diwajibkan membayar denda 50 (lima puluh) juta rupiah subsider kurungan tiga bulan karena dinilai tidak cermat dalam mencairkan anggaran sehingga mengakibatkan kerugian negara. Dalam proses kasus tersebut, tidak ada sedikitpun bantuan hukum yang diberikan oleh pemerintah, padahal berdasarkan peraturan perundang-undangan seharusnya mendapatkan perlindungan hukum (bantuan hukum) dari pemerintah.

Tidak hanya kasus yang menimpa PPK Bea Cukai Jawa Timur saja, masih banyak kasuskasus serupa di Indonesia khususnya di Jawa Timur yang dalam prosesnya tidak mendapatkan perlindungan berupa bantuan hukum dari pemerintah puasat maupun daerah.

Berdasarkan faktor-faktor penghambat diatas, maka sudah seharusnya untuk mengatur secara khusus melalui Undang-Undang terkait dengan Pengadaan Barang/Jasa Pemerintah. Dengan mengatur secara jelas dan rinci perlindungan hukum terhadap seluruh pelaku pengadaan barang/jasa pemerintah yang di dalamnya juga meliputi Pejabat Pembuat Komitmen (PPK). Disamping itu, di era otonomi daerah seperti sekarang ini juga penting peran pemerintah daerah dalam memberikan perlindungan hukum kepada pelaku pengadaan barang/jasa pemerintah, salah satunya ialah dengan mengatur pengadaan barang/jasa pemerintah kedalam sebuah Peraturan Daerah (Perda). Sehingga nantinya pelaku pengadaan barang/jasa pemerintah tersebut lebih terlindungi secara hukum.

\section{c. Konstruksi Hukum Agar Pejabat Pembuat Komitmen dalam Pengadaan Barang/Jasa Pemerintah Terlindungi}

Melihat kenyataan tersebut di atas, lemahnya perlindungan hukum bagi penyelenggara pengadaan barang/jasa pemerintah diperlukan adanya sebuah undangundang yang mengatur secara khusus tentang penyelenggaraan pengadaan barang/jasa pemerintah. Hal ini dirasa perlu karena penyelenggara butuh perlindungan hukum dari suatu aturan setara undang-undang yang mengatur khusus penyelenggaraan pengadaan barang/jasa pemerintah, mengatur tentang prosedur penanganan masalah hukum secara terpadu, mengatur tentang siapa yang berwenang dalam penanganan laporan atau pengaduan tentang adanya indikasi pelanggaran prosedur dan indikasi tindak pidana.

Sehingga, dengan adanya undangundangan ini yang mengatur dengan jelas pihakpihak yang berwenang khusus dalam penanganan pelanggaran pidana, administrasi dan/atau perdata dalam penyelenggaraan pengadaan barang/jasa pemerintah, dapat memberikan kepastian bagi penyelenggara pengadaan barang/jasa pemerintah. Tidak seperti selama ini.

Bentuk perlindungan hukum terhadap penyelenggara pengadaan barang/jasa pemerintah yang akan diatur dalam UndangUndang nantinya yang paling krusial untuk diatur secara khusus ialah mengenai hal-hal berikut ini:

1) Adanya penegasan tentang prosedur penanganan pelanggaran yang sifatnya pidana, hukum administrasi dan hukum pidana. Hal ini dimaksudkan agar terdapat kepastian mengenai jalur mana yang harus ditempuh oleh para pihak bila terjadi pelanggaran pada ketiga bagian hukum tersebut (perdata, administrasi dan pidana);

2) Adanya penegasan tentang siapa yang berwenang untuk melakukan penyelidikan dan/atau penyidikan bilamamana ada indikasi pelanggaran dalam Penyelenggaraan PBJ;

3) Adanya penegasan tentang tahap mana diperbolehkan oleh undang-undang untuk dilakukan penyelidikan/penyidikan dalam penyelenggaraan PBJP; dan

4) Adanya pengaturan yang jelas tentang koordinasi dan pembagian kewenangan antara lembaga terkait yang berwenang dalam penanganan pelanggaran atau pengawasan dalam penyelenggaraan PBJP, seperti: Kementrian, Lembaga, Pemerintah Daerah, Instansi terkait lainnya.

Sembari menunggu lahirnya undangundang yang khusus mengatur tentang pengadaan barang/jasa pemerintah sebagaimana diuraikan sebelumnya, upaya terpenting yang harus dilaksanakan adalah adanya political will dari para stakeholders dalam memberikan 
perlindungan hukum bagi pelaku pengadaan barang/jasa. Karena tidak cukup dengan hanya nota kesepahaman (MoU) yang sudah ada antara Kejaksaan, Kepolisian dan Badan Pengawas Keuangan dan Pembangunan (BPKP) Nomor: KEP-109/A/JA/09/2007, B/2718/IX/2007, KEP-1093/K/D6/2007 pada tahun 2007.

Nota kesepahaman ini dirasakan tidak berarti apa-apa tanpa adanya keseriusan pimpinan ketiga lembaga ini untuk dapat menjalankan isi kesepahaman tersebut sampai kepada jajaran dibawahnya. Karena pada dasarnya tidak ada sanksi yang dapat dikenakan kepada salah satu pihak yang melanggar kesepahaman tersebut. Tapi yang dituntut adalah niat baik dan kemauan politik (political will) seluruh elemen yang terkait dalam penyelenggaran pengadaan barang/jasa pemerintah.

Bila dilihat apa yang diatur dalam nota kesepahaman tersebut, sebenarnya sudah ada kesepahaman bagi ketiga lembaga ini dalam penanganan perkara yang termasuk dalam ruang lingkup kerjasama tersebut, termasuk didalamnya PBJP, dimana dinyatakan dalam Pasal 4 ayat (1) yang berbunyi: "Dalam hal terdapat kasus/masalah, termasuk pengadaan barang dan jasa yang dapat menghambat laju pembangunan nasional, maka pimpinan instansi melakukan koordinasi." Kemudian ayat (2) diuraikan bahwa: "Dalam hal dari hasil koordinasi diperlukan pendalaman, maka BPKP melakukan audit terlebih dahulu atas kasus/masalah sebagaimana dimaksud pada ayat (1)." Kemudian terkait adanya indikasi tindak pidana diatur pada ayat (4) yang berbunyi: "Dalam hal dari hasil audit sebagaimana dimaksud pada ayat (2) diketahui adanya penyimpangan yang berindikasi tindak pidana korupsi, maka BPKP melakukan audit investigatif dan melaporkan hasilnya dalam rapat koordinasi maupun kepada intsansi penyidik untuk ditindaklanjuti."

Kiranya jelas apa yang dimaksudkan pada ayat (3) tersebut di atas, dimana dalam hal adanya indikasi tindak pidana (korupsi) dalam penyelenggaraan pengadaan barang/jasa pemerintah maka tidak dengan serta merta kepolisian atau kejaksaan melakukan proses penyelidikan/penyidikan. Diutamakan adanya audit dari BPKP tentang adanya indikasi korupsi yang berakibat pada kerugian keuangan negara.

$$
\text { Faktanya bahwa isi nota }
$$

kesepahaman/kerjasama ini dirasakan tidak menyentuh sampai ke daerah kabupaten/kota.
Selama ini masih saja terdapat oknum aparat kepolisian yang melakukan pemanggilan dan pemeriksaan terhadap penyelenggara pengadaan barang/jasa pemerintah bahkan baru pada tahap pengumuman pelelangan.

Seyogyanya, dengan adanya nota kesepahaman ini secara langsung dapat memberikan perlindungan bagi penyelenggara pengadaan barang/jasa pemerintah tentang kepastian hukum dalam penangan pelanggaran dalam penyelenggaraan pengadaan barang/jasa pemerintah.

Tidak cukup dengan membuat peraturan khusus terkait dengan perlindungan hukum bagi pelaku pengadaan barang/jasa pemerintah melalui peraturan perundang-undangan, di era otonomi seperti sekarang ini juga perlu adanya perlindungan hukum yang diberikan oleh Pemerintah Daerah melalui Peraturan Daerah.

Perlindungan hukum dan bantuan hukum yang diberikan oleh Pemerintah Daerah melalui Peraturan Daerah nantinya akan memberikan jaminan perlindungan hukum bagi para pelaku pengadaan barang/jasa pemerintah. Tidak hanya bagi pelaku pengadaan barang/jasa pemerintah, perlindungan hukum tersebut juga berlaku bagi seluruh anggota ASN di wilayah daerah tersebut, sehingga diharapkan dengan adanya perlindungan dan bantuan hukum tersebut akan meningkatkan kinerja dan produktivitas dari segenap ASN di wilayahnya.

\section{PENUTUP}

Perlindungan hukum terhadap pelaku pengadaan barang/jasa pemerintah pada sistem pengadaan secara elektronik yang dalam hal ini adalah PPK belum terlindungi, itu disebabkan oleh tidak adanya aturan khusus yang mengatur terkait dengan perlindungan hukum terhadap pelaku pengadaan barang/jasa tersebut. Dalam peraturan perundang-undangan yang terkait tidak secara rinci menjelaskan terkait dengan perlindungan hukum yang bagaimana yang diberikan, artinya peraturan-peraturan tersebut tidak efektif dalam memberikan perlindungan hukum kepada pelaku pengadaan barang/jasa pemerintah khususnya PPK. Yang diatur dalam Peraturan Presiden tersebut ialah hanya tata cara pengadaan barang/jasa pemerintah beserta kewenangan dan tugas PPK, tidak ada yang mengatur secara jelas terkait perlindungannya.

Idealnya agar pelaku pengadaan barang/jasa pemerintah khususnya Pejabat Pembuat Komitmen (PPK) terlindungi, ialah dengan mengatur secara khusus terkait 
perlindungan hukum dalam sebuah peraturan perundang-undangan dan juga perlu untuk masing-masing daerah mengatur terkait dengan pengadaan barang/jasa pemerintah beserta perlindungannya dalam sebuah Peraturan Daerah (Perda). Sehingga nantinya pelaku pengadaan barang/jasa pemerintah lebih terlindungi dalam melaksanakan tugastugasnya, tampa harus ada kekhawatiran adanya diskriminasi dan kriminalisasi kepadanya.

\section{DAFTAR PUSTAKA}

Buku-Buku/Jurnal/Website

Anonimous, 2014. Penggunaan Eprocurement Pelatihan Tingkat Dasar Pengadaan Barang/Jasa Pemerintah Berdasarkan Peraturan Presiden No. 54 Tahun 2010 Beserta Perubahannya, Deputi Bidang PPSDM, LKPP

Grasia Kurniati, 2017. Akibat Hukum Pelanggaran Prosedur Pengadaan Barang/Jasa Pemerintah dan Perlindungan Hukum Terhadap Organisasi Pengadaan Barang/Jasa Pemerintah, Jurnal Hukum POSITUM Vol. 1 No. 2, Juni 2017

ICW. 2005. Prinsip Dasar Kebijakan Dan Kerangka Hukum Pengadaan Barang dan Jasa, Jakarta: Indonesian Procurement Watch

Kumorotomo, Wahyudi, Jurnal Masalah Kelembagaan Dalam Reformasi Pengadaan Barang Dan Jasa Di Indonesia

Manan, Bagir, 1996. Peranan Hukum Administrasi Negara Dalam Pembentukan Peraturan PerundanganUndangan (makalah disampaikan pada Peraturan Nasional Hukum Acara dan Hukum Administrasi Negara Fakultas Hukum Universitas Hasanudin

Mirhan Triandi, Mendorong (Kembali) Lahirnya Undang-Undang Pengadaan Barang/Jasa, Artikel dalam (https://birokratmenulis.org/mendorongkembali-lahirnya-undang-undang- pengadaan-barang-jasa/), diakses tanggal 09 Februari 2019

No Name, 5 Arahan Presiden Jokowi untuk Mempercepat Penyerapan Anggaran, Artikel dalam (https://news.detik.com/berita/2999977/ini -5-arahan-jokowi-untuk-percepatpenyerapan-anggaran), diakses tanggal 10 Februari 2019

No Name, Laporan Tahunan Bagian Pengdaan Barang/Jasa dalam (http://bagianpbj.kutaibaratkab.go.id/wpco ntent/uploads/2017/09/Laporn-Tahunan2017-Bagian-PBJ-website.pdf, diakses pada tanggal 10 Mei 2008)

Sedamaryanti, 2003. Good Governance dalam Rangka Otonomi Daerah Upaya Membangun Organisasi Efektif dan Efesien Melalui Restrukturisasi dan Pemberdayaan, Bandung, Mandar Maju

Simamora, Yohanes Sogar, 2009. Hukum Perjanjian Prinsip Hukum Kontrak Pengadaan Barang dan Jasa oleh Pemerintah, Yogyakarta: LaksBang PRESSindo

\section{Peraturan Perundang-Undangan}

Undang-Undang Nomor 5 Tahun 2014 tentang Aparatur Sipil Negara (ASN)

Undang-Undang Nomor 23 tahun 2014 tentang Pemerintahan Daerah

Peraturan Pemerintah Nomor 11 Tahun 2017 tentang Manajemen Pegawai Negeri Sipil

Peraturan Presiden Republik Indonesia Nomor 4 tahun 2015 tentang Perubahan Keempat Atas Peraturan Presiden Nomor 54 tahun 2010 tentang Pengadaan Barang/Jasa Pemerintah.

Peraturan Presiden Republik Indonesia Nomor 16 tahun 2018 tentang Pengadaan Barang/Jasa Pemerintah

Peraturan Menteri Keuangan Nomor 190/PMK.05/2012 tentang Tatacara Pembayaran Dalam Rangka Pelaksanaan Anggaran Pendapatan dan Belanja Negara 